\title{
Chemical Composition and Antibacterial Activities of Goniothalamus marcanii Flower Essential Oil
}

\author{
Sakon Monggoot, Patcharee Pripdeevech* \\ School of Science, Mae Fah Luang University, 57100 Chiang Rai, Thailand.
}

\section{ARTICLE INFO \\ Article history: \\ Received on: 25/09/2016 \\ Revised on: 18/11/2016 \\ Accepted on: 03/12/2016 \\ Available online: $31 / 01 / 2017$}

\section{Key words:}

Goniothalamus marcanii, essential oil, GC-MS, antibacterial activity, Minimum inhibitory

concentration.

\begin{abstract}
The essential oil of Goniothalamus marcanii flowers extracted by hydrodistillation was investigated in terms of its chemical composition by gas chromatography-mass spectrometry with their retention indices. The analyses revealed the presence of 116 compounds, representing $93.83 \%$ of the essential oil. The major compounds of the oil were caryophyllene oxide, $E$-caryophyllene, $\alpha$-humulene, $\delta$-cadinene and linalool. Essential oil of Goniothalamus marcanii flowers were tested in vitro antibacterial activities against six human pathogens including Staphylococcus epidermidis, Staphylococcus aureus, Staphylococcus agalactiae, Proteus mirabilis, Escherichia coli and Salmonella typhimurium by using agar paper disc diffusion assay. Flower oil of Goniothalamus marcanii exhibited broad spectrum antibacterial activities along with their respective minimum inhibitiory concentration values ranging from 15.62 to $1000 \mu \mathrm{g} / \mathrm{mL}$ according to various terpenes and its derivatives.
\end{abstract}

\section{INTRODUCTION}

The genera Goniothalamus (Annonaceae) contains approximately 160 species (Saunders, 2003). These plants are ancient shrubs and tree lets distributing in tropical and subtropical Asia such as Malaysia and Thailand (Saunders and Chalermglin, 2008). They have been broadly considered as sources for natural products with potential anticancer (Seyed et al., 2014), antiplasmodial, antimycobacterial, cytotoxic, antimicrobial and antibacterial activities (Calixto et al., 2012). The leaves of G. macrophyllus and G. giganteus are used to treat fever while the roots of G. macrophyllus and G. scortechinii are used to cure post-partum and abortion (Abdullah et al., 2013; Choo et al., 2014). The roots of G. tapis are used as abortifacient during pregnancy with a few months and treat typhoid fever (Colegate et al., 1990). The seeds of G. amuyon are used to treat

* Corresponding Author

Dr. Patcharee Pripdeevech, School of Science,

Mae Fah Luang University, 57100 Chiang Rai, Thailand.

Email: patcharee.pri @mfu.ac.th scabies, rheumatism and tympanites (Ahmad et al., 1991; Macabeo et al., 2013; Pradupsri et al., 2009). Characterizations of the chemical constituents of Goniothalamus plants resulted in the isolation of bioactive compounds including styryllactones, alkaloids, annonaceous acetogenins, flavonoids, azaanthraquinones and naphthoquinones (Cao et al., 1998). Essential oils from Goniothalamus leaves and stem barks mainly consists of monoterpenoid and sesquiterpenoids (Jantan et al., 2003). Stem bark oil of $G$. cardiopetalus and $G$. cylindrostigma exhibited strong inhibitory activity against Staphylococcus epidermidis and Candida albicans (Hisham et al., 2006). The essential oils from the twig and root of G. macrophyllus showed strong antimicrobial properties against Vancomycin intermediate-resistance $S$. aureus, S. epidermidis and C. albicans (Humeirah et al., 2010). Goniothalamus marcanii, known as Khao Lam in Thai, is planted widely in the northern, northeastern and southern regions of Thailand (Saunders and Chalermglin, 2008). It is a shrub tree with smooth, thin and fibrous trunk. The leaves are simple, alternate and exstipulate. Its flowers are axillary greenish yellow with specific aromatic fragrance. 
In Thailand, G. marcanii are used treating for infectious diseases in early childhood under 5 years old (Mahiwan et al., 2013). Phytochemical investigation of $G$. marcanii leaf and twig demonstrated the presence of non-volatile compounds including 1azaanthraquinone and naphthoquinone derivatives with cytotoxicity against human tumor cell lines including lung carcinoma, colon adenocarcinoma, breast carcinoma, melanoma and brain carcinoma (Soonthornchareonnon et al., 1999). Recently, three styryllactones including 5-hydroxygoniothalamin, 5-acetylgoniothalamin and goniopypyrone were isolated from $G$. marcanii leaves and twigs with potential anticancer activities in cell lines (Mahiwan et al., 2013).

Essential oils, also known as volatile oil, are aromatic oily viscous liquid derived from different parts of plants. They have been traditionally known to demonstrate pharmacological effects such as anti-inflammatory, antioxidant, cytotoxic properties (Sindhu et al., 2010; Baser and Buchbauer 2015). Essential oils are also used as naturalcides against broad range of bacterial (Rondón et al., 2016), fungal, viral (Ibrahim et al., 2015) and protozoal pathogens (Dai et al., 2010). According to less toxic and biodegradation properties comparing to synthetic antibiotics and preservatives, essential oils from plants possesses great potential for their antimicrobial activities in the medicine and food industry (Koul et al., 2008). To the best of our knowledge, the chemical composition and antibacterial activities of G. marcanii flower oil have not yet been explored. Therefore, this research aims to investigate the essential oil composition of $G$. marcanii flower as well as its antibacterial activities which will be tested against human pathogenic bacteria.

\section{MATERIAL AND METHODS}

\section{Plant materials}

The flowers of G. marcanii were collected in June 2016 at the health garden, Mae Fah Luang University, Chiang Rai, Thailand. A voucher specimen (MFL No. 10002) was deposited at Mae Fah Luang Botanical Garden, Mae Fah Luang University, Chiang Rai, Thailand.

\section{Essential oil isolation}

The G. marcanii flowers were subjected to hydrodistillation for 3 hours using a modified Clevenger-type apparatus. After extraction the distillate was collected in a conical flask which was then dried over anhydrous $\mathrm{Na}_{2} \mathrm{SO}_{4}$. The oil obtained was kept in a sealed vial until required with a yield of $0.62 \% \mathrm{w} / \mathrm{w}$.

\section{Gas chromatography-mass spectrometry (GC-MS) analysis}

The chemical composition of $G$. marcanii flower oil obtained from hydrodistillation was analyzed using a Hewlett Packard model HP6890 gas chromatograph (Agilent Technologies, Palo Alto, CA, USA) equipped with an HP-5MS (5\% phenylpolymethylsiloxane) capillary column $(30 \mathrm{~m} \times 0.25 \mathrm{~mm}$ i.d., film thickness $0.25 \mu \mathrm{m}$; Agilent Technologies, USA) interfaced to an
HP model 5973 mass-selective detector. The oven temperature was initially held at $60{ }^{\circ} \mathrm{C}$ and then increased by $3{ }^{\circ} \mathrm{C} / \mathrm{min}$ to 220 ${ }^{\circ} \mathrm{C}$. The injector and detector temperatures were 250 and $280{ }^{\circ} \mathrm{C}$, respectively. Purified helium was used as the carrier gas at a flow rate $1 \mathrm{ml} / \mathrm{min}$. EI mass spectra were collected at $70 \mathrm{eV}$ ionization voltages over the range of $\mathrm{m} / \mathrm{z} 29-300$. The electron multiplier voltage was $1150 \mathrm{~V}$. The ion source and quadrupole temperatures were set at 230 and $150{ }^{\circ} \mathrm{C}$, respectively. Identification of volatile components was performed by comparison of their Kovat retention indices, relative to $\mathrm{C}_{8}-\mathrm{C}_{23}$ n-alkanes, and using a comparison of the mass spectra of individual components with the reference mass spectra in the Wiley 7N and NIST05 databases. The quantity of all identified components was investigated by using a percent relative peak area as shown in Table 1.

\section{Pathogenic bacteria}

The human pathogenic bacteria used in this study were Gram-positive bacterial strains i.e., Staphylococcus epidermidis DMST 15505, S. aureus DMST 8840 and S. agalactiae DMST 17129, Gram-negative bacterial strains i.e., Proteus mirabilis DMST 8212, Escherichia coli DMST 4212 and Salmonella typhimurium DMST 562. These bacteria were obtained from Department of Medical Science, Ministry of Health, Bangkok, Thailand. The bacterial strains were revived for bioassay by subculturing in tryptic soy broth medium for 24 hours before testing.

\section{Screening for antibacterial activity}

Antibacterial activity was done by modifying a method of Rajendran et al. (2014). The paper disc diffusion method was used to investigate for antibacterial activity of $G$. marcanii flower oil. Each human pathogenic bacterial strain was uniformly spread using sterile cotton swab on a sterile Petri dish Muller Hinton agar after adjusted to $0.5 \mathrm{McF}$ arland standard. A sterilized 6-mm of paper disc (Whatman ${ }^{\mathrm{TM}}$, USA) was added with $30 \mu \mathrm{L}$ of difference essential oil concentration and then placed on the infusion agar individually. The essential oils with different concentrations were prepared using dichloromethane as a solvent by two-fold dilution, $(1000,500,250,125,62.50,31.25,15.627 .81$ and $3.91 \mu \mathrm{g} / \mathrm{mL})$, then further dropped on to each paper disc (30 $\mu \mathrm{L}$ per paper disc). The treated plates were incubated at $37{ }^{\circ} \mathrm{C}$ for 24 hours. The antimicrobial activity was determined, using a ruler to measure the sizes in diameter of a paper disc including the inhibition clear zone. A negative control was also performed in the test, using a filter paper disc saturated with dichloromethane. Moreover, Chloramphenicol antibiotic dissolved in distilled water was also used as a reference control and each experiment was carried out in triplicate. Finally, the minimum inhibition concentration (MIC) defined as the lowest concentration of an essential oil extract that prevent bacterium growth was also done.

\section{RESULTS AND DISCUSSION}

The GC-MS chromatogram and all identified volatile compounds, the relative area percentages and their retention 
indices are summarized in Fig. 1 and Table 1, respectively. The $G$. marcanii flower oil contained 116 volatile components representing $93.83 \%$ of the oil were identified. The major components were caryophyllene oxide (19.28\%), E-caryophyllene $(14.58 \%), \quad \beta$-copaene $(4.16 \%), \alpha$-humulene $(3.64 \%), \quad 1$-epicubenol $(3.37 \%)$, linalool $(3.28 \%)$ and $\delta$-cadinene $(3.25 \%)$. Ciscadin-4-en-7-ol (2.79\%), 3E-cembrene A (2.77\%), isolongifolan7- $\alpha$-ol $\quad(2.76 \%), \quad$ trans-cadina-1(6),4-diene $\quad(2.61 \%)$, sesquithuriferol $(2.24 \%)$ and vulgarone B $(2.21 \%)$ were also found to be minor components of the $G$. marcanii flower oil (Adams, 2007; König et al., 1999; Thang et al., 2013).

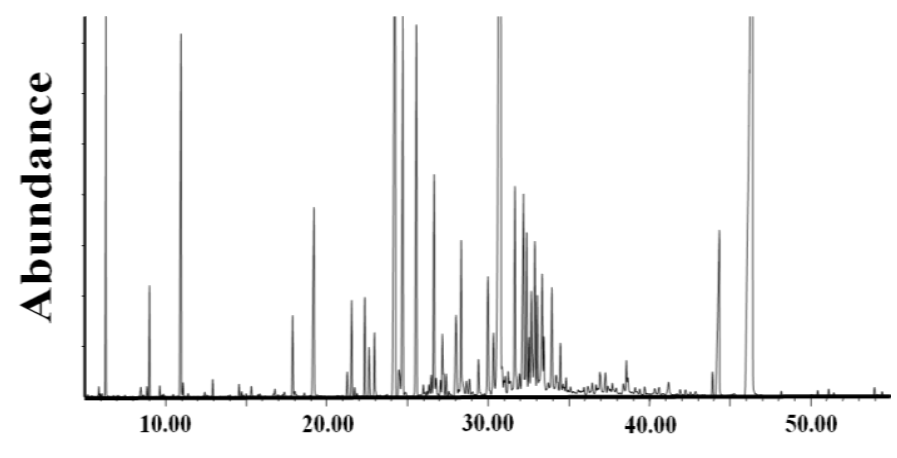

Time (min)

Fig. 1: GC-MS chromatogram of essential oil of G. marcanii flowers.

Table 1: Volatile constituents of essential oil of G. marcanii flowers.

\begin{tabular}{|c|c|c|c|c|}
\hline No. & $\begin{array}{c}\text { Retention } \\
\text { time (min) }\end{array}$ & Compound & RI & $\begin{array}{c}\begin{array}{c}\text { \% Peak } \\
\text { area }\end{array} \\
\end{array}$ \\
\hline 1 & 5.86 & 3-methyl cyclohexanol & 935 & 0.10 \\
\hline 2 & 5.94 & $\beta$-citronellene & 942 & 0.11 \\
\hline 3 & 6.05 & $\alpha$-fenchene & 945 & 0.12 \\
\hline 4 & 6.28 & benzaldehyde & 952 & 2.54 \\
\hline 5 & 6.78 & sabinene & 969 & 0.09 \\
\hline 6 & 6.99 & $\beta$-pinene & 979 & 0.07 \\
\hline 7 & 7.11 & cis-meta-mentha-2,8-diene & 983 & 0.08 \\
\hline 8 & 7.51 & yomogi alcohol & 999 & 0.09 \\
\hline 9 & 8.48 & benzyl alcohol & 1025 & 0.11 \\
\hline 10 & 8.64 & sylvestrene & 1026 & 0.14 \\
\hline 11 & 8.85 & benzene acetaldehyde & 1032 & 0.07 \\
\hline 12 & 9.01 & $E$ - $\beta$-ocimene & 1044 & 0.71 \\
\hline 13 & 9.40 & $\gamma$-terpinene & 1054 & 0.06 \\
\hline 14 & 9.64 & acetophenone & 1059 & 0.12 \\
\hline 15 & 9.77 & trans-arbusculone & 1066 & 0.06 \\
\hline 16 & 9.88 & cis-linalool oxide (furanoid) & 1067 & 0.06 \\
\hline 17 & 10.47 & trans-linalool oxide (furanoid) & 1084 & 0.09 \\
\hline 18 & 10.71 & methyl benzoate & 1088 & 0.08 \\
\hline 19 & 10.92 & linalool & 1095 & 3.28 \\
\hline 20 & 11.08 & $\alpha$-pinene oxide & 1099 & 0.09 \\
\hline 21 & 11.39 & phenyl ethyl alcohol & 1106 & 0.08 \\
\hline 22 & 12.32 & dihydro-linalool & 1131 & 0.07 \\
\hline 23 & 12.42 & benzeneacetonitrile & 1134 & 0.06 \\
\hline 24 & 12.57 & $E$-epoxy-ocimene & 1137 & 0.17 \\
\hline 25 & 12.66 & trans-limonene oxide & 1137 & 0.16 \\
\hline 26 & 12.92 & trans-verbenol & 1140 & 0.12 \\
\hline 27 & 13.65 & $\beta$-pinene oxide & 1154 & 0.05 \\
\hline 28 & 13.99 & iso-isopulegol & 1155 & 0.07 \\
\hline 29 & 14.53 & $\alpha$-terpineol & 1186 & 0.17 \\
\hline 30 & 14.69 & methyl salicylate & 1190 & 0.06 \\
\hline 31 & 14.81 & cis-dihydro carvone & 1191 & 0.07 \\
\hline 32 & 14.98 & trans-4-caranone & 1196 & 0.08 \\
\hline 33 & 15.29 & cis-4-caranone & 1200 & 0.09 \\
\hline 34 & 15.71 & trans-carveol & 1215 & 0.06 \\
\hline
\end{tabular}

\begin{tabular}{|c|c|c|c|c|}
\hline 35 & 15.85 & $\beta$-cyclocitral & 1217 & 0.07 \\
\hline 36 & 16.65 & pulegone & 1233 & $\mathrm{t}$ \\
\hline 37 & 16.76 & cumin aldehyde & 1238 & 0.08 \\
\hline 38 & 16.95 & carvone & 1239 & 0.09 \\
\hline 39 & 17.23 & geraniol & 1249 & 0.09 \\
\hline 40 & 17.36 & cis-myrtanol & 1250 & 0.07 \\
\hline 41 & 17.86 & $E$-cinnamaldehyde & 1267 & 0.75 \\
\hline 42 & 18.00 & tetrahydro-lavandulol acetate & 1268 & 0.09 \\
\hline 43 & 18.58 & neryl formate & 1280 & 0.05 \\
\hline 44 & 18.94 & $\gamma$-terpinen-7-al & 1290 & 0.06 \\
\hline 45 & 19.13 & 1-nitro-2-phenyl ethane & 1294 & 2.11 \\
\hline 46 & 21.25 & $\alpha$-cubebene & 1345 & 0.19 \\
\hline 47 & 21.52 & $\alpha$-longipinene & 1350 & 0.91 \\
\hline 48 & 21.71 & neoiso-dihydro carveol acetate & 1356 & 0.11 \\
\hline 49 & 21.86 & $Z$ - $\beta$-damascenone & 1361 & 0.06 \\
\hline 50 & 22.34 & $\alpha$-copaene & 1374 & 0.83 \\
\hline 51 & 22.61 & $E$-methyl cinnamate & 1376 & 0.41 \\
\hline 52 & 22.93 & $\beta$-cubebene & 1387 & 0.59 \\
\hline 53 & 23.17 & sativene & 1390 & 0.08 \\
\hline 54 & 23.30 & $\alpha$-chamipinene & 1396 & 0.05 \\
\hline 55 & 23.61 & $\alpha$-funebrene & 1402 & 0.07 \\
\hline 56 & 23.73 & italicene & 1405 & 0.06 \\
\hline 57 & 24.19 & $E$-caryophyllene & 1417 & 14.58 \\
\hline 58 & 24.46 & cis-thujopsene & 1429 & 0.05 \\
\hline 59 & 24.69 & $\beta$-copaene & 1430 & 4.16 \\
\hline 60 & 24.87 & isoamyl benzoate & 1433 & 0.06 \\
\hline 61 & 25.55 & $\alpha$-humulene & 1452 & 3.64 \\
\hline 62 & 25.76 & $\alpha$-patchoulene & 1454 & 0.06 \\
\hline 63 & 25.98 & dehydro-aromadendrene & 1460 & 0.07 \\
\hline 64 & 26.08 & $\gamma$-decalactone & 1465 & 0.06 \\
\hline 65 & 26.22 & cis-thujopsadiene & 1465 & 0.07 \\
\hline 66 & 26.33 & dauca-5,8-diene & 1471 & 0.08 \\
\hline 67 & 26.48 & $\alpha$-neocallitropsene & 1474 & 0.09 \\
\hline 68 & 26.62 & trans-cadina-1(6),4-diene & 1475 & 2.61 \\
\hline 69 & 26.77 & amorpha-4,7(11)-diene & 1479 & 0.07 \\
\hline 70 & 27.05 & $\alpha$-amorphene & 1483 & 0.08 \\
\hline 71 & 27.17 & germacrene D & 1484 & 1.13 \\
\hline 72 & 27.40 & cis- $\beta$-guaiene & 1492 & 0.08 \\
\hline 73 & 27.56 & viridiflorene & 1496 & 0.07 \\
\hline 74 & 28.01 & $\delta$-amorphene & 1511 & 0.09 \\
\hline 75 & 28.19 & eugenol acetate & 1521 & 0.08 \\
\hline 76 & 28.33 & $\delta$-cadinene & 1522 & 3.25 \\
\hline 77 & 28.65 & zonarene & 1528 & 0.05 \\
\hline 78 & 28.85 & $\gamma$-cuprenene & 1532 & 0.05 \\
\hline 79 & 29.03 & furopelargone $\mathrm{A}$ & 1538 & 0.06 \\
\hline 80 & 29.40 & italicene epoxide & 1547 & 0.43 \\
\hline 81 & 29.98 & $E$-nerolidol & 1561 & 1.49 \\
\hline 82 & 30.34 & dendrolasin & 1570 & 0.06 \\
\hline 83 & 30.69 & caryophyllene oxide & 1582 & 19.28 \\
\hline 84 & 31.22 & viridiflorol & 1592 & 0.55 \\
\hline 85 & 31.63 & sesquithuriferol & 1604 & 2.24 \\
\hline 86 & 31.91 & epi-cedrol & 1618 & 0.09 \\
\hline 87 & 32.15 & isolongifolan-7- $\alpha$-ol & 1618 & 2.76 \\
\hline 88 & 32.34 & 1-epi-cubenol & 1627 & 3.37 \\
\hline 89 & 32.51 & 5-cedranone & 1628 & 0.05 \\
\hline 90 & 32.64 & $\beta$-cedren-9-one & 1631 & 0.06 \\
\hline 91 & 32.86 & cis-cadin-4-en-7-ol & 1635 & 2.79 \\
\hline 92 & 33.01 & hinesol & 1640 & 0.08 \\
\hline 93 & 33.31 & vulgarone B & 1649 & 2.21 \\
\hline 94 & 33.42 & pogostol & 1651 & 0.05 \\
\hline 95 & 33.93 & $E$-amyl cinnamaldehyde & 1667 & 1.44 \\
\hline 96 & 34.18 & 5-iso-cedranol & 1672 & 0.46 \\
\hline 97 & 34.44 & khusinol & 1679 & 1.38 \\
\hline 98 & 34.79 & $Z$-apritone & 1689 & 0.05 \\
\hline 99 & 35.91 & sedanenolide & 1719 & 0.17 \\
\hline 100 & 36.16 & guaiol acetate & 1725 & 0.19 \\
\hline 101 & 36.42 & curcumenol & 1733 & 0.23 \\
\hline 102 & 36.89 & $2 E, 6 E$-farnesol & 1745 & 0.68 \\
\hline 103 & 37.24 & $\beta$-Z-curcumen-12-ol & 1754 & 1.05 \\
\hline 104 & 38.35 & $\gamma$-eudesmol acetate & 1783 & 0.09 \\
\hline
\end{tabular}




\begin{tabular}{lllll}
\hline $\mathbf{1 0 5}$ & 38.53 & $\beta$-eudesmol acetate & 1792 & 1.21 \\
$\mathbf{1 0 6}$ & 38.64 & $\alpha$-eudesmol acetate & 1794 & 0.09 \\
$\mathbf{1 0 7}$ & 41.16 & $Z$,Z-farnesyl acetone & 1860 & 0.31 \\
$\mathbf{1 0 8}$ & 43.89 & cembrene & 1938 & 0.28 \\
$\mathbf{1 0 9}$ & 44.29 & 3E-cembrene A & 1947 & 2.77 \\
$\mathbf{1 1 0}$ & 48.14 & canellal & 2045 & 0.15 \\
$\mathbf{1 1 1}$ & 50.41 & laurenan-2-one & 2115 & 0.17 \\
$\mathbf{1 1 2}$ & 51.10 & nezukol & 2132 & 0.14 \\
$\mathbf{1 1 3}$ & 51.40 & osthole & 2140 & 0.19 \\
$\mathbf{1 1 4}$ & 53.99 & catalpalactone & 2199 & 0.18 \\
$\mathbf{1 1 5}$ & 54.10 & $\alpha$-santonine & 2203 & 0.17 \\
$\mathbf{1 1 6}$ & 54.38 & phyllocladanol & 2209 & 0.18 \\
\hline \multicolumn{4}{c}{ Total $(\%)$} & 93.83 \\
& \multicolumn{5}{c}{ Essential oil yield (\%) } \\
\hline
\end{tabular}

RI: retention index on HP-5MS column; t: trace amount $<0.05$

The essential oil of $G$. marcanii flowers showed antibacterial activities against all tested bacterial pathogens (Table 2). A strong inhibitory effect against all tested pathogens was recorded as compared with chloramphenicol antibiotic. The flower oil of $G$. marcanii at the concentration of $1000 \mu \mathrm{g} / \mathrm{ml}$ diluted with dichloromethane $(30 \mu \mathrm{L})$ exhibited the strong antibacterial properties against all tested human pathogenic bacteria ranging from $13.3 \mathrm{~mm}$ to $23.5 \mathrm{~mm}$. A significant antibacterial activity of the $G$. marcanii flower oil was detected against $E$. coli and $S$. aureus. However, the G. marcanii flower oil revealed a moderate antibacterial activity against $S$. epidermidis, $S$. agalactiae, $S$. typhimurium and P. mirabilis.

Table 2: Inhibition zone diameter of bacterial pathogens by essential oil of $G$. marcanii flowers ( $30 \mu \mathrm{L}$ corresponding to concentration of $\mathbf{1 0 0 0} \mu \mathrm{g} / \mathrm{mL})$.

\begin{tabular}{lc}
\hline \multicolumn{1}{c}{ Bacteria } & inhibition zone diameter $(\mathbf{m m})$ \\
\hline Gram-positive & \\
S. agalactiae DMST 17129 & $14.7 \pm 1.4$ \\
S. aureus DMST 8840 & $19.5 \pm 2.7$ \\
S. epidermidis DMST 15505 & $14.9 \pm 1.8$ \\
Gram-negative & \\
P. mirabilis DMST 8212 & $13.3 \pm 1.7$ \\
S. typhimurium DMST 562 & $13.5 \pm 2.1$ \\
E. coli DMST 4212 & $23.5 \pm 3.1$ \\
\hline
\end{tabular}

MIC values described as the lowest concentrations of $G$. marcanii flower oil that provided complete growth inhibition of all the test pathogens and inhibition zone diameter are also demonstrated in Table 3. The MIC value was against the most susceptible species of $E$. coli and $S$. aureus marked as 15.62 $\mu \mathrm{g} / \mathrm{mL}$ and $31.25 \mu \mathrm{g} / \mathrm{mL}$, followed by $S$. epidermidis, $S$. agalactiae, $S$. typhimurium and $P$. mirabilis with $125 \mu \mathrm{g} / \mathrm{mL}, 125$ $\mu \mathrm{g} / \mathrm{mL}, 125 \mu \mathrm{g} / \mathrm{mL}$ and $1000 \mu \mathrm{g} / \mathrm{mL}$, respectively. As can be noticed, the antibacterial properties of the G. marcanii flower oil could be attributed to the occurrence of high proportions of terpenes and its derivatives in the oil as indicated by the work of (Abdelwahab et al., 2009) and (Zengin and Baysal, 2014) due to various functional groups among these voaltile components. Antibacterial properties of $G$. marcanii flower oil might be related to compounds containing a high potential in strong inhibiting bacterial pathogens. These volatile components are considered to play an important role as antibacterial agents including caryophyllene oxide, $E$-caryophyllene, $\alpha$-humulene, 1-epicubenol, linalool, sesquithuriferol and vulgarone B corresponding to the high amount presented in the G. marcanii flower oil (Lago et al., 2011).

Conversely, the antibacterial activity was independant significantly of the amount of the volatie components. Therfore, some minor compounds such as acetophenone, dihydro-linalool, iso-isopulegol, $\beta$-cyclocitral, carvone and geraniol could be also corelated to its antibacterial properties. MIC values of $G$. marcanii flower oil ranged from 15.62 to $1000 \mu \mathrm{g} / \mathrm{ml}$ exhibited board range of antibacterial activity. The results indicated that the $G$. marcanii flower oil possessed bacteriostatic and bactericidal activities and demonstrated great potential as an antibacterial compound.

The obtained results for the antibacterial activity of the G. marcanii flower oil were correlated to accordance with Hisham et al. (2006), Wiart (2007) and Humeirah et al. (2010) who reported that Goniothalamus essential oils obtained from some species have potent antibacterial activities against the human pathogens such as $S$. epidermidis and $S$. aureus. The mode of action of the $G$. marcanii flower oil as antimicrobial agents may be due to inhibition of respiration and disrupting the permeability barriers of the cell membrane structures (Cox et al., 2000).

Table 3: Antibacterial activity expressed as inhibition zone diameter ( $\mathrm{mm}$ ) and MIC $(\mu \mathrm{g} / \mathrm{mL})$ of essential oils of $G$. marcanii flowers and chloramphenicol.

\begin{tabular}{|c|c|c|c|c|}
\hline \multirow[b]{2}{*}{ Bacteria } & \multicolumn{2}{|c|}{$\begin{array}{c}\text { inhibition zone diameter } \\
(\mathbf{m m})\end{array}$} & \multicolumn{2}{|c|}{ MIC $(\mu \mathrm{g} / \mathrm{mL})$} \\
\hline & 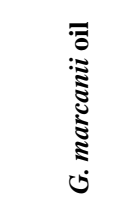 & 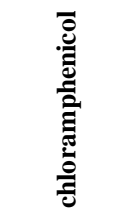 & 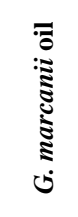 & 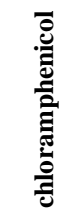 \\
\hline \multicolumn{5}{|l|}{ Gram-positive } \\
\hline S. agalactiae DMST 17129 & $0.84 \pm 0.9$ & $14.2 \pm 1.1$ & 500 & 15.62 \\
\hline S. aureus DMST 8840 & $10.7 \pm 1.8$ & $12.4 \pm 2.1$ & 31.25 & 15.62 \\
\hline $\begin{array}{l}\text { S. epidermidis DMST } \\
15505\end{array}$ & $9.8 \pm 1.5$ & $9.2 \pm 1.4$ & 125 & 15.62 \\
\hline Gram-negative & & & & \\
\hline P. mirabilis DMST 8212 & $13.3 \pm 1.7$ & - & 1000 & - \\
\hline S. typhimurium DMST 562 & $13.5 \pm 2.1$ & - & 1000 & - \\
\hline E. coli DMST 4212 & $10.5 \pm 2.1$ & $10.3 \pm 2.1$ & 15.62 & 7.81 \\
\hline
\end{tabular}

-: not detected

\section{CONCLUSION}

The antibacterial activity of the essential oil extracted from $G$. marcanii flowers was due to the synergism between the various volatile components and mainly attributed to the presence of caryophyllene oxide, $E$-caryophyllene, $\beta$-copaene, $\alpha$-humulene, 1-epi-cubenol, linalool and $\delta$-cadinene as major constituents. The broad range antibacterial activities of the $G$. marcanii flower oil against variety of tested human pathogenic bacteria, can recommend its incorporation in different pharmaceutical applications. 


\section{ACKNOWLEDGEMENT}

We are grateful to the Department of Medical Science, Ministry of Health, Bangkok, Thailand and the Scientific \& Technological Instruments Center, Mae Fah Luang University for bacterial pathogens and a $\mathrm{PhD}$ research instruments.

Financial support and sponsorship: The authors also acknowledge the financial support from the Office of the Postgraduate Studies, Mae Fah Luang University.

Conflict of Interests: There are no conflicts of interest.

\section{REFERENCES}

Abdelwahab SI, Abdul AB, Elhassan MM, Mohan S, Ibrahim MY, Mariod AA, AlHaj NA, Abdullah R. GC/MS determination of bioactive components and antibacterial properties of Goniothalamus umbrosus extracts. Afr J Biotechnol, 2009; 8:3336-3340.

Abdullah N, Sahibul-Anwar H, Ideris S, Hasuda T, Hitotsuyanagi Y, Takeya K, Diederich M, Choo C. Goniolandrene A and B from Goniothalamus macrophyllus. Fitoterapia, 2013; 88:1-6.

Adams RP. 2007, Identification of essential oil components by gas chromatography/mass spectroscopy, Allured Publishing Corporation, Illinois, USA.

Ahmad FB, Tukol WA, Omar S, Sharif AM. 5-Acetyl goniothalamin, a styryl dihydropyrone from Goniothalamus uvaroides. Phytochemistry, 1991; 30:2430-2431.

Baser KHC, Buchbauer G. 2015. Handbook of essential oils: science, technology, and applications. Florida, USA. CRC Press.

Calixto JB, Campos MM, Otuki M F, Santos AR. Antiinflammatory compounds of plant origin. Part II. Modulation of proinflammatory cytokines, chemokines and adhesion molecules. Planta Med, 2004; 70:93-103.

Cao SG, Wu XH, Sim KY, Tan B, Pereira J, Goh SH. Styryllactone derivatives and alkaloids from Goniothalamus borneensis (Annonaceae). Tetrahedron, 1998; 54:2143-2148.

Choo CY, Abdullah N, Diederich M. Cytotoxic activity and mechanism of action of metabolites from the Goniothalamus genus. Phytochem Rev, 2014; 13:835-851.

Colegate SM, Din LB, Latiff A, Salleh KM, Samsudin MW, Skelton BW, Tadano KI, White AH, Zakaria Z. (+)-Isoaltholactone: A furanopyrone isolated from Goniothalamus species. Phytochemistry, 1990; 29:1701-1704

Cox S, Mann C, Markham J, Bell H, Gustafson J, Warmington $\mathrm{J}$, Wyllie S. The mode of antimicrobial action of the essential oil of Melaleuca alternifolia (tea tree oil). J Appl Microbiol, 2000; 88:170-175.

Dai T, Huang YY K, Sharma S, Hashmi TJ, Kurup BD, Hamblin RM. Topical antimicrobials for burn wound infections. Recent Pat Antiinfec Drug Discov, 2010; 5:124-151.

Hisham A, Pathare N, Al-Saidi S, Jayakumar G, Bhai AM, Harikumar B. The composition and antimicrobial activity of stem bark essential oil of Goniothalamus cardiopetalus (B1.) Hook. f. et Thoms. J Essent Oil Res, 2006; 18:451-454.

Humeirah AS, Azah MN, Mastura M, Mailina J, Saiful J, Muhajir H, Puad A. Chemical constituents and antimicrobial activity of Goniothalamus macrophyllus (Annonaceae) from Pasoh Forest Reserve, Malaysia Afr J Biotechnol, 2010; 9:5511-5515.

Ibrahim, NA, El-Hawary SS, Mohammed M, Farid MA, AbdelWahed NA, Ali MA, El-Abd E A. Chemical composition, antiviral against avian influenza (H5N1) virus and antimicrobial activities of the essential oils of the leaves and fruits of Fortunella margarita, Lour. swingle, growing in Egypt. J App Pharm Sci 2015; 5:6-12.

Jantan I, Ahmad F, Ahmad A. A comparative study of the essential oils of four Goniothalamus species. Paper presented at the III WOCMAP Congress on Medicinal and Aromatic Plants-Volume 3: Perspectives in Natural Product Chemistry 2003; 677.
König WA, Bülow N, Saritas Y. Identification of sesquiterpene hydrocarbons by gas phase analytical methods. Flavour Fragr J, 1999; 14:367-378

Koul O, Walia S, Dhaliwal G. Essential oils as green pesticides: potential and constraints. Biopestic Int, 2008; 4:63-84

Lago JHG, Souza ED, Mariane B, Pascon R, Vallim MA, Martins RCC, Baroli AA, Carvalho BA, Soares MG, dos Santos RT, Sartorelli P. Chemical and biological evaluation of essential oils from two species of myrtaceae-Eugenia uniflora L. and Plinia trunciflora (O. Berg) Kausel. Molecules, 2011; 16:9827-9837.

Macabeo A PG, Lopez ADA, Schmidt S, Heilmann J, Dahse HM, Alejandro GJD, Franzblau SG. Antitubercular and cytotoxic constituents from Goniothalamus gitingensis. Rec Nat Prod, 2013; 8:4145 .

Mahiwan C, Buayairaksa M, Nuntasaen N, Meepowpan P, Pompimo W. Potential cancer chemopreventive activity of styryllactones from Goniothalamus marcanii. Am J Appl Sci, 2013; 10:112-116.

Moharam BA, Jantan I, Jalil J, Ahmad F. Inhibitory effect of compounds from Goniothalamus tapis Miq. and Goniothalamus uvaroides king on platelet-activating factor receptor binding. Phytother Res ,2012; 26:687-691.

Pradupsri P, Loetchutinat C, Nuntasaen N, Meepowpan P, Tuntiwechapikul W, Pompimon W. Anticancer activities of styrylpyrone from the leaves and twigs of Goniothalamus maewongensis via cell cycle arrest. Am J Appl Sci, 2009; 6:2018-2023.

Rajendran MP, Pallaiyan BB, Selvaraj N. Chemical composition, antibacterial and antioxidant profile of essential oil from Murraya koenigii (L.) leaves. Avicenna J Phytomed, 2014; 4:200-214.

Rondón ME, Velasco J, Cornejo X, Fernández J, Morocho V. Chemical composition and antibacterial activity of Piper lenticellosum CDC essential oil collected in Ecuador. J App Pharm Sci, 2016; 6:156159.

Saunders RM. A synopsis of Goniothalamus species (Annonaceae) in Peninsular Malaysia, with a description of a new species. Bot J Linn Soc, 2003; 142:321-339.

Saunders RM, Chalermglin P. A synopsis of Goniothalamus species (Annonaceae) in Thailand, with descriptions of three new species. Bot J Linn Soc, 2008; 156:355-384.

Seyed MA, Jantan I, Bukhari S N A. Emerging anticancer potentials of Goniothalamin and its molecular mechanisms. BioMed Res Int, 2014; Article ID 536508.

Sindhu RK, Upma KA, Arora S. Santalum album Linn: a review on morphology, phytochemistry and pharmacological aspects. Intl J PharmTech Res, 2010; 2:914-919.

Soonthornchareonnon N, Suwanborirux K, Bavovada R, Patarapanich C, Cassady JM. New cytotoxic 1-azaanthraquinones and 3aminonaphthoquinone from the stem bark of Goniothalamus marcanii. J Nat Prod, 1999; 62:1390-1394.

Thang TD, Dai DN, Hoi TM, Ogunwande IA. (2013). Chemical compositions of the leaf essential oils of some Annonaceae from Vietnam. J Essent Oil Res, 2013; 25:85-91.

Wiart C. Goniothalamus species: a source of drugs for the treatment of cancers and bacterial infections. Evid Based Complement Alternat Med, 2007; 4:299-311.

Zengin H, Baysal AH. Antibacterial and antioxidant activity of essential oil terpenes against pathogenic and spoilage-forming bacteria and cell structure-activity relationships evaluated by SEM microscopy. Molecules 2014; 19:17773-17798.

\section{How to cite this article:}

Monggoot S, Pripdeevech P. Chemical Composition and Antibacterial Activities of Goniothalamus marcanii Flower Essential Oil. J App Pharm Sci, 2017; 7 (01): 144-148. 